\title{
Over-the-counter medications potentially inappropriate for the elderly
}

The use of over-the-counter medication - with no need for prescriptions - is part of human behaviour'. The Brazilian Health Regulatory Agency (Anvisa) does not consider that to be a relevant factor for public health since they periodically publish a list of overthe-counter medications that are deemed of low-risk for patient health and/or adequate for treating less severe conditions for short periods of time ${ }^{2}$.

It is noteworthy that self-medicating poses a potential for adverse reactions and drug interactions just like prescription drugs. That is even more palpable for patients, such as the elderly, who make longterm concurrent use of several medications ${ }^{3}$.

The common knowledge that the elderly often face serious drug interaction problems and adverse reactions led Beers et $\mathrm{al}^{4-8}$ (1991, 1997, 2003, 2012, and 2015) to develop a set of criteria for potentially inappropriate medications for 65-year-old adults or older. Potentially inappropriate medications (PIM) for the elderly are defined as those that present higher risks of causing adverse effects than of generating benefits for patients in this age group.

There are several other lists of PIM for the elderly, and they are all useful in clinical practice to assist in the prevention of iatrogenesis ${ }^{9-12}$. However, since
Beers' criteria are the most reviewed, updated and most often cited in the literature, they have become the essential reference for PIM for the elderly.

Thus, that is the question that inspired this editorial: Are there, among over-the-counter medications in Brazil, any potentially inappropriate medications for the elderly?

We analyzed a list of drugs exempt from prescriptions that was published on the Diário Oficial da União on October 30 2016, according to the Beers' criteria $(2015)^{2,8}$. We found that five therapeutic groups included in the criteria - $14.3 \%$ of the groups total were present on the list of drugs analyzed (antacids/ antiemetics, antispasmodics, antihistamines, anti-inflammatory, and muscle relaxants) $)^{2,8}$.

The version of the Beer's criteria used (2015) does not include topical medications and eye drops, which were present on the list of drugs exempt of prescription ${ }^{2,8}$.

Considering that the elderly make long-term concurrent use of several medications, inappropriate use has become a common situation among this age group ${ }^{1,13}$. Self-medicating contributes to the development of drug interactions and adverse effects - often attributed to pre-existing conditions and/or the "age" 
factor -, which in turn leads to the prescription of other drugs by the health professional, to minimize the symptoms ${ }^{1,13-15}$. Before that decision - referred to as a prescription cascade - it is also worth to ask the patient about the use of over-the-counter medications ${ }^{15,16}$.

Even if we consider the self-medicating process greater than that of the use of over-the-counter medications, we must acknowledge and measure the inherent health risk caused by the frequent use of this type of drug. That is the justification for the objective of this editorial and the use of Beers' criteria (2015) as a quantitative and qualitative assessment scale for over-the-counter medications ${ }^{8}$.

Halila et $\mathrm{l}^{17}$ (2015) analyzed systematic reviews published on over-the-counter medications and their effectiveness and safety. They found that most of the studies included in the review were favorable to the use of some of these medications but considered that some therapeutic groups require greater evidence to be considered safe for free consumption. The categories of drugs that are exempt from prescription considered PIM for the elderly according to the Beers' criteria (2015) - antacids/antiemetics, antispasmodics, antihistamines, anti-inflammatory, and muscle relaxants - were included amongst those in need of concrete evidence regarding their safety ${ }^{2,8,17}$ Even though this was not the point of this editorial, the systematic review by Reis e Figueiras $^{18}$ (2010) on the week evidence of effectiveness and safety of cough medication registered in Brazil is noteworthy. The same is said about the variations in quality of seven different brands of dipyrone (oral solution) sold in drugstores in cities in the interior of the state of Paraná, as observed by Knappmann e Melo $^{19}$ (2010).

Seeking to identify the instruments that assess the quality of prescriptions written for the elderly and which drugs could be considered PIM for this age group, Varallo et al..$^{20}$ (2014) conducted a review of publications on the subject and identified 15 in- struments, including a version of the Beers' criteria before $2015^{7}$. They considered $15.2 \%$ of the over-thecounter drugs sold in Brazil to be PIM for the elderly, a number close to that found by this editorial (14.3\%).

These numbers are incredibly relevant, for $26 \%$ of the elderly who attended the Elderly Healthcare Clinic of the Hospital of the Catholic University of Brasilia declared they self-medicated, and $40 \%$ of these medications were over-the-counter. The types of medication most often used with no medical supervision were nonsteroidal anti-inflammatories, analgesics, antipyretics, phytotherapics, and those of cardiovascular action'.

Clinical practice often finds situations similar to those described above. Some elderly patients self-medicate with nonsteroidal anti-inflammatories, antipyretics or muscle relaxants to make the journey from home to the clinic and the wait there more comfortable, or due to insomnia caused by night pains. This behavior is often kept from health professionals and has the potential to alter, for example, arterial pressure, thus triggering the previously mentioned prescription cascade ${ }^{13-15}$.

Therefore, even if considered of low iatrogenesis risk, when asking elderly patients about the use of medication, one should always ask specifically about over-the-counter drugs due to their potential for drug interactions and adverse effects in patients of this age group. Equally important in the verification of PIM for the elderly, for it reduces the risk of severe adverse reactions to the pharmacotheraphy ${ }^{21}$.

In conclusion, there is a significant percentage of potentially inappropriate medications for the elderly, according to Beers' criteria (2015), that are sold in Brazil exempt from a prescription. These criteria are useful to prevent the use of potentially inappropriate medications for the elderly that are sold over-the-counter, even though they do not include all types of medication that are exempt from prescription in Brazil.

\section{REFERENCES}

1. Bortolon PC, Medeiros EFF, Naves JOS, Karnikowski MGO, Nóbrega OT. Análise do perfil de automedicação em mulheres idosas brasileiras. Ciênc Saúde Colet. 2008;13(4):1219-26.

2. Diário Oficial da União No. 189 - Seção 1. Instrução Normativa - In No. 11, de 29 de Setembro de 2016. Pg. 99.

3. Rozenfeld S. Prevalência, fatores associados e mau uso de medicamentos entre os idosos: uma revisão. Cad Saúde Pública. 2003;19(30):717-24.

4. Beers MH, Ouslander JG, Rollingher I, Reuben DB, Brooks J, Beck JC. Explicit criteria for determining inappropriate medication use in nursing

home residents. UCLA Division of Geriatric Medicine. Arch Intern Med. 1991;151(9):1825-32.

5. Beers $\mathrm{MH}$. Explicit criteria for determining potentially inappropriate medication use by the elderly. An update. Arch Intern Med. 1997;157(14):1531-6.

6. Fick DM, Cooper JW, Wade WE, Waller JL, MacLean JR, Beers MH. Updating the Beers criteria for potentially inappropriate medication use in older adults: results of a US consensus panel of experts. Arch Intern Med. 2003;163(22):2716-24.

7. American Geriatrics Society 2012 Beers Criteria Update Expert Panel. 
American Geriatrics Society updated Beers Criteria for potentially medication use in older adults. J Am Geriatr Soc. 2012;60(4):616-31.

8. The American Geriatrics Society 2015 Beers Criteria Update Expert Panel. American Geriatrics Society 2015 Updated Beers Criteria for Potentially Inappropriate Medication Use in Older Adults. I Am Geriatr Soc 2015;63(11):2227-46

9. McLeod PJ, Huang AR, Tamblyn RM, Gayton DC. Definig inappropriate practices in prescribing for elderly people: a national consensus panel. CMAJ. 1997;156(3):385-91.

10. Gallagher O, O'Mahony D. STOPP (Screening Tool of Older Persons' potentially inappropriate Prescriptions): application to acutely ill elderly patients and comparison with Beers' criteria. Age Ageing. 2008;37(6):673-9.

11. Holt S, Schmiedl S, Thürmann PA. Potentially inappropriate medications in the elderly: the PRISCUS list. Dtsch Arztebl Int. 2010;107(31-32):543-51.

12. Oliveira MG, Amorin WW, Borja-Oliveira CR, Coqueiro HL, Gusmão LC, Passos LC. Consenso brasileiro de medicamentos potencialmente inapropriados para idosos. Geriatr Gerontol Aging. 2016;10(4):168-81.

13. Rozenfeld S. Prevalência, fatores associados e mau uso de medicamentos entre idosos: uma revisão. Cad Saúde Pública. 2003;19(3):717-24.

14. Marin MJS, Cecílio LCO, Perez AEWUF, Santella F, Silva CBA, Gonçalves
Filho IR, Roceti LC. Caracterização do uso de medicamentos entre idosos de uma unidade do Programa Saúde da Família. Cad Saúde Pública. 24(7): 1545-1555

15. Rochon PA, Gurwitz JH. Optimising drug treatment for elderly people: the prescribing cascade. BMJ. 315: 1096-1099.

16. Teixeira ||V, Lefèvre F. A prescrição medicamentosa sob a ótica do paciente idoso. Rev Saúde Pública. 2001; 35(2): 207-213.

17. Halila GC, Czepula AIS, Otuki MF, Correr C). Review of the efficacy and safety of over-the-counter medicine. BJPS. 2015; 51(2): 403-414

18. Reis AMM, Figueiras A. Analysis of evidence of efficacy of over-thecounter cough medications registered in Brazil. BJPS. 2010; 46(1): 135-145.

19. Knappmann AL, Melo EB. Qualidade de medicamentos isentos de prescrição: um estudo com marcas de Dipirona comercializadas emu ma drogaria de Cascavel (PR, Brasil). Ciênc Saúde Coletiva. 2010; 15(Supl 3): 3467-3476.

20. Varallo FR, Oliveira FM, Mastroianni PC. Safety assessment of essential medicines for elderly people: a bibliographic survey. BJPS. 2014; 50(2): 269-284.

21. Mastroianni PC, Varallo FR, Barg MS, Noto AR, Galduróz ICF. Contribuição do uso de medicamentos para a admissão hospitalar. BJPS. 2009; 45(1); $163-170$ 